\title{
E-Word of Mouth: Strengthening the Strategic Tool of Digital Marketing
}

\author{
Anurag Singh
}

\begin{abstract}
Electronic Word of Mouth (e-WoM), has developed into one of the most dominant source of information in recent years, in all the fields of product and service industry, with the arrival of web based platforms. It is being widely used in all the areas to seek the information and facilitate communication, particularly in marketing. As more and more customer are adapting to this technological changes, e-WoM is getting a crucial role in shaping consumer behaviour. The e-WOM, due to high impact on the behaviour of consumer, has been a vital concept used by researchers in recent times. But the related literature remains heterogeneous in spite of the rising number of studies, which might impact the comprehensive understanding of e-Word of Mouth in long term. In the backdrop of the problem, this chapter systematically reviews of the concepts, through available but splintered literature on e-WoM. The chapter ends with the stories of successful companies, applied $e$-WoM in past with managerial implications.
\end{abstract}

Keywords : e-Word of Mouth, Strategy, Social Media, Stories, Strengthen.

\section{INTRODUCTION}

Word of mouth communication has always been one of the most preferred and prevalent way of communication (Dellarocas, 2003), and this is the reason that it has always been an interest area for researchers and marketers. According to Katz \& Gurevitch (1973), Word of Mouth not only exchanges the marketing information but also plays a pivotal role in determining the consumer attitude and behaviour for a particular product or services (Mishra \& Singh, 2017). Thus, WoM is a way of communication among the consumers about a product, service, or company where the source of information is considered free from any influence of the firm (Litvin et al., 2008). These exchanges are interpersonal in nature and give the firm access to important information, such as consumption pattern of the consumer, which is beyond the formal advertising (Brown et al., 2007). In the context of consumer behaviour, Word of Mouth is considered as one of the most prominent factor (Daugherty and Hoffman, 2014). So, marketers always look the new ways to connect the customer through word of mouth communication. But it has always been difficult for the marketers to control and coordinate Word of Mouth communication method. Internet and advent of Smartphone and social media solved this problem.

Revised Manuscript Received on September 22, 2019.

* Correspondence Author

Anurag Singh, Associate Professor, Institute of Management Studies, Banaras Hindu University, Varanasi, India.
E Word of Mouth (e-WoM) is one of the tools, which facilitated the path of effective communication and marketing strategy. e-WoM, with the advent of web based platforms, has developed into one of the most dominant source of information in recent years (Abubakar \& Ilkan, 2016), especially in services industry (Sotiriadis \& Van Zyl, 2013). As more and more customer are adapting to this technological changes, e-Word of Mouth is getting a crucial role in shaping consumer behaviour (Gómez-Suárez et al., 2017, Cantallops \& Salvi, 2014). E-Word of Mouth enables the consumer to discuss with each other and also influences the consumer (Reza \& Samiei, 2012) by sharing experiences of product and services usage with each. Many Industries especially Hospitality has been frontrunner in grabbing this opportunity of interaction with their consumers. They invite customers on their web based portals to share their experiences and views. Experiences and views about product or services facilitate companies to understand the customers' expectations without conducting surveys. Moreover, the consumer's satisfaction is also gauged by the marketer.

The e-WOM, because of its large impact on consumer behaviour, has been an important concept for researchers and has majorly focused in the recent times. But the related literature remains heterogeneous in spite of the rising number of studies, as the term e-WoM is not conceptualized properly, which might impact the studies related to e-WoM. Therefore this chapter aims to highlight the concepts of e-WoM to give a conceptual frame and also narrates the story of companies successfully implemented e-WoM in past. Chapter ends with the implications for the manager.

\section{Theoretical Frame of E-WoM}

Various attempts to define the term Electronic Word of Mouth communication have led to few definitions with some disagreement about the coverage of various digital phenomenons under the term.

As per Henning- Thurau (2004), "e -WoM communication refers to any positive or negative statement made by a potential, actual and former customer about the product or a company via the internet." This includes attributes of traditional Word of Mouth platform with added features of Internet technology spanning all customers' types and types of statement. This definition of e-WoM was criticized by many researchers. Thorson \& Rodgers (2006) advocated that consumer and consumer communication in online medium cannot be restricted and it can happen at various others level too. It is also important to notice that in e-Word of Mouth, there is a chance that person who is communicating is even

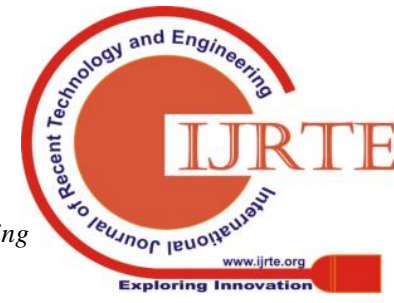


not a consumer (Breazeale, 2009).

Litvin et.al., (2008) defines e-WoM as "all information technology directed at consumer through internet-based technology related to the usage or characteristics of particular goods and services or there sellers" The description included messaging between the consumer and the marketer and communication among customers. Though, they are integral part of Electronic Word of Mouth flow, but they are distinctly different from communication through mass media (Kim et. al., 2011). Companies are eager to align themselves with Electronic WoM as it gives them advantage of fetching real time data and reaching large number of consumers without spending large expenses which are essential in traditional marketing.

\subsection{Significance of e-WoM in Marketing:}

To effectively use the e-WoM's marketing and its power, 'virality' is always the first term marketers consider for using. However, the word of mouth in marketing has an extreme effect on the brand and its power building, which is far beneficial than the campaigns floated as viral (ACNielson, 2007). There are many reasons why the e-Word of mouth use is so significant in marketing (Litvin et.al, 2008).

First reason is that it is tough to get confidence in the business world. The strength of the marketing with the help of WoM/ e-WoM increases the possibility of the product/brand use by the customers. to build faith in their customers, companies creates brand ambassadors, which shares experience of products or services with their network. A study shows that 92 percent of the customer trusts people's recommendations of their peer group as well as indefinite reviews through e-WoM builds the trust in 70 percent of the customers.

Secondly, having new customers with a company is a challenge, which can be converted into opportunities after associating the customer through the customer reference program. Customers to whom a peer refers are generally more loyal to a brand than the company developed customers otherwise. If the friends or relatives are connected with the same establishment, the customer continues to become more committed. If using the same approach through e-WoM, it would be more influential due to very high connectivity of customers with internet and social media.

Thirdly, e-WoM provides a tool that constantly flows through the company. The development of buzz increases both positive and negative influences. Furthermore, in the past, brand buzz creation has found that it affects the brand image unless it is negative.

\section{2. e-WoM Classification and Applications:}

As there is disagreement among researchers in relation to the definition of Electronic Word of Mouth, likewise disparities are evident with regard to the typologies of Electronic Word of Mouth. Different researchers have suggested different typologies of Electronic Word of Mouth. Mayfield (2008) has classified e-WoM on the basis of various digital platforms such as Blogs, Social Networks, and Virtual Communities. On the other hand, Chevalier \& Mayzlin (2006), have classified e-WoM on the basis of valence of e-WoM communication i.e. +ve or -ve. The categories/ classification of e-WoM are 'One to One', 'One to Many', 'Many to Many' and 'Many to One' (Litvin et. al., 2008).

Social Media platforms also fall under this classification. Instant Messaging App such as Whatsapp and WeChat falls in One to One category of e-Word of Mouth. Whereas, Facebook and Twitter falls in the category of One to Many.

\subsection{Theoretical base and factors of e-WoM influence:}

In social media, e-WoM information may be provided in various ways. One side, users can inform about the brand and on the other side, can post the details of the products/servie (Litvin et.al, 2008). Moreover, customers can exhibit their preferences to their network knowingly, for example, turning into a fan of brand, communicating with brand threads by liking or disliking and making comments to promote brand content. People, who find e- WoM thread in social media, try to understand information thoroughly so as to use information for buying purpose. In past studies, e-WoM and its influence have been examined by researchers using various models and theories.

\subsubsection{Technology acceptance model (TAM):}

Davis (1989) proposed TAM theory, which is extensively used and accepted, aimed to identify behavior problems of customers in accepting new technologies. TAM is more specific to the information system (Fishbein \& Ajzen, 1975). TAM is supported by two main structures, perceived usefulness and perceived ease of use. It predicts the attitude of an individual towards the acceptance of certain technologies. As a result, researchers used TAM in various circumstances, like the study of internet use, social media use, internet banking, internet education, and e-governance. Furthermore, TAM is also used to describe the use of info in the e-WoM perspective. However, the TAM has also been widely criticized due to its limited explanatory powers although it's considered as a major model. In the development and execution of information, it is revealed that TAM spotlights on the human being use of computers only with the perceived usefulness concept and ignores key social procedures. TAM offers ample explanation of consumer attitudes and intents, especially for e-WOM, where information is produced by independent person (Ayeh, 2015). Moreover, TAM is criticized by researchers because, while focusing on use, TAM neglects the link between intent and real behavior (Bagozzi 2007).

\subsubsection{Information Adoption Model (IAM):}

e-WoM discussion includes general information move among two person who sends and receives the contnet. The impact of the specific information could perhaps change from individual to individual; the same content could elicit different conceptions between recipients. Past studies concentrated on the procedure of information adoption to comprehend the people internalize the information they get. Researchers have used TRA/ TAM models in the information systems based researches in order

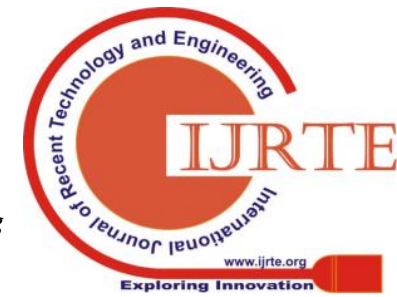


to describe how people adopts the ideas and information (Mishra \& Singh 2018). Including TAM (Davis, 1989), and the theory of the Elaboration likelihood model (Petty and Cacioppo, 1980), the IAM was proposed (Sussman and Siegal, 2003) to work, in the light of the fact that two different messages, the central and peripheral, influence the people involved. The central route alludes to the message core, while the peripheral route alludes to the concerns that are connected to the message core indirectly. The arguments quality (central route), the credibility of the source (peripheral route), information usefulness and information adoption are the four components of IAM. The IAM provides this integration to illustrate how communication through computer platform works for people. This model is ardently relevant for e-WoM, online discussion forums, and social media studies because it illustrates the information about communication platforms through computer (Shu and Scott, 2014).

\subsubsection{Theory of Reasoned Action (TRA):}

It is proposed in TRA that intentions are based on antecedents of behaviour, i.e., behavioural attitudes and subjective norms. In previous research on the association among electronic word of mouth and purchasing intent, TRA has been commonly used (Cheung \& Thadani 2012). The relationship between e-WoM and purchasing intentions, though, uses only two TRA modules i.e. attitude and behaviour intention. A substantial theories, like TRA, theory of planned behaviour (TPB) and TAM, recognize behavioural intent to be the antecedent of actual behaviour. However, previous and current studies were criticized in buying behaviour, as buying behaviour, is subject to unforeseen changes in income and unanticipated promotions (Duhan \& Singh, 2013a). Subjective norms allude to how others will see them if their behaviour was performed. Moreover, (Duhan \& Singh, 2013b), argued that if the personality of a person is not influenced by the thinking of others, the predictive intent and behaviour will have little influence due to subjective norms.

\section{SuCCESS STORIES OF E-WORD OF MOUTH}

\subsection{Netflix:}

Netflix, is one of the most prominent online media service providers, uses e-Word of Mouth on regular basis to inform its user about their popular shows such as House of Cards, Sacred Games and Narcos. Netflix was amongst the few companies which expanded its reach with the help of E Word of Mouth (Sugita, 2018). They started focussing on programs (Like House of Card which is a Netflix Original) which were different from daily soap operas of Television. They started the programs with different concept so that viewers can discuss about them. These discussions were felicitated by Netflix through various e-Word of Mouth platforms such as Twitter and Facebook. Through such discussion Netflix tried to understand the user sentiment and then delivered the expected values of viewers (Sugita, 2018). Netflix afterwards shares viewer excitement on e-WoM platform which prompt interest among other viewers.

\subsection{Facebook:}

Mark Zuckerberg's basic thought behind starting this tech-giant was facilitated by understanding the problems of the customers and marketers and then addressed the need of e-Word of Mouth Platform. With 2.27 bn energetic users per month, FB have developed as biggest online community of the globe, out of its total monthly users, 1.49 billion users log into Facebook (FB) daily (Zephoria Digital Marketing, 2018). Facebook is not only a Social Media platform for individual but it is a wonderful platform for any marketer. Marketers accept that Facebook is important or critical for their business. Average time a person gives to Facebook is 20 minutes daily. Having 20 minutes of 1.49 billion users shows the immense scope to marketers for the usage of FB in business (Dellarocas, 2003). The biggest advantage or disadvantage of Facebook is Viral Post. Facebook gives a platform to its user to post their views, opinion, pleasure or displeasure. Sometime if a view or opinion is shared by many users again and again, then that post goes viral. This Viral post has an important impact on trade and growth of a company.

\subsection{Arab Spring:}

In between 2010 and 2012, the biggest turn of event in recent history was Arab Spring. In Several countries of Middle East and Arabia, people started protesting against their autocratic government (Martin and Simone, 2012). Protest was organized using SM platforms like FB and Twitter. Videos of this protest were circulated to different part of Arab World through Youtube and other Social Media sites. This protest led to change of regime in three countries i.e. Egypt, Tunisia and Yemen. This shook the government of many other Arabian Countries including Syria, Saudi Arabia and Bahrain. They have to bring in moderate measures to deal with this protest and made many administrative changes in there working (Martin and Simone, 2012). Recent liberal outreach by Saudi Government towards women is seen as an example of these measures. The turning action took place due to multiplied effects of making the issue viral and continued threaded discussion on Arab Spring.

\subsection{Chipotle:}

In order to share with its customers its unique characteristics of local supplements, Chitpole has taken the social media to apply e-WoM marketing technique called "buzz" (McMillen, 2016). In most cases, companies generate discussions on their goods and spread awareness by using electronic word of mouth buzz. To boost discussion on this feature, Chipotle developed a game app and a video. Using game app and a video was very successful because it brought over 614 million constructive thoughts and criticism on social media.

\subsection{RedBull:}

Based on the successful e-WoM campaigns in the past, RedBull world market leader in energy drinks, wanted to build the electronic 'RedBull Reporters' as the effective marketing strategy. To this end, Red Bull sponsored news stories around the Red Bull brand by journalism and film students (Dougherty, 2015). A massive number of entries enabled the company to reap 
the rewards for RedBull's good experiences.

As at present, companies have changed their WoM strategies to match today's technological advances, but is not clear about the changes may take place in future. It can be a good, a bad, a cyclic, or an innovative (Dougherty, 2015). Several people are using word-of-mouth techniques to promote things with friends and credible sources so, if things are executed, the process of e-WoM will be influential. The effect of e-WoM will be high as there are always sensible people around, with any brilliant idea, to tamper, edit, and improve. If e-WoM; continues in attracting the trust of the people, and is applied with the effects of tampered, edited and improved idea it could bring unexpected changes.

\section{MANAGERIAL IMPLICATIONS:}

Going back to our memories, here, again when, we relied on families and friends' advice for anything from cars to the best soap brand. This type of word review was clear cut and easy at one time. Then the technology became part of the world and the way in which we interact with known, changed dramatically to the unknown. We now depend more than ever before on unknown virtual network friends throughout our technology- driven world. It's not just about creating messages; it's about providing the masses with true human experiences. Intelligent marketers and company executives choose the most vital information type, i.e. the e- word, on which customers focus on, when thinking to purchase.

Consumers are supported through e- words of the mouth to become passionate for any issue, including products and services. Converting an individual to a consumer depends on how marketers talk and share the message with their network. The thoughtful e-WoM generates an understanding and benefits for the brand. In view of the generating understanding for the consumers and benefits to the company, below is a discussion and explanation of strategies to be applied to make e- word of mouth effective.

\subsection{Identify the Influencers and Target them:}

Influencers include social media players and bloggers who promote the online brand message. Beer (2019) argued that real impact leads not only knowledge but action also. The fact is that buyer trusts the third party review rather than promotion by advocacy. Sending the right message to influencer is a new method of marketing that can lead to explosive business growth if done effectively. It is necessary for the marketer to ensure the identification of costumes which are really aimed for promotion (Beer, 2019). Active with capability within a certain virtual network can have a lot to do.

Abbott Group, a company founded in the USA, created clinical, medical, nutritional and generic drug breakthroughs. A brand called Pediasure was introduced by the company in India to benefit society lead healthier lives. Abbott Nutrition struggled to develop its market in the rural market of India (Singh, 2014). Moreover, their TV advertisements didn't build the type of awareness wanted by Abbott Nutrition, even after having very expensive ads. The company immediately worked closely with the Advocacy group of e- WoM intending towards endorser mother for e-Word of Mouth. The enterprise also allocated forty eight thousand specimens to four thousand young mothers, each of whom received one kit and 10 additional kits for their close friends (Jhagadia, 2014). The promotional drive was an enormous achievement, with a core audience reach of forty $\%$. Brand recognition grew 5 times in 5 months, purchase doubled and sales rose within just 8 weeks.

\subsection{Understand Human Emotions and Connect It:}

Human care through a social media campaign is effective in the generation of human emotions. There are numerous commercials of Television that, in the history, produced human feelings through human being. The strategy of concerning human feelings in marketing campaigns of social media via personal touch has now become prevalent. Elle in India is also the example of the same. Elle inched forward in the pink ribbon effort by generating $\mathrm{Fb}$ page aimed to women's empowerment. Their brand ambassador Sonam Kapoor endorsed to spread this message via the e- WoM. They have combat with several brands that have helped Elle with discounts, charities etc in order to fight this disease. To have efficient approach, people have to load their selfies in pink colour clothes on social media to promote the unique initiative of Elle on breast cancer in India. Prominent Bollywood actors such as Sonam Kapoor, Nargis Fakhri and other posted their \# PinkSelfie, to encourage their feat to follow and discuss the drive aimed to fight breast cancer (Ians, 2017).

Because of its unique e-Word of Mouth campaign, Elle obtained an impressive 2,5 million hits over two days with 1,89 million social opinions, as well as a huge number of Instagram and Twitter sharing of pictures directing the motivation of society for charity (Ians, 2017). The Social Media campaign has been extremely successful and has long been debated.

\subsection{Continuous Community Involvement:}

The participation of the community is another important focus needed to build the Strategy efficient. Continuous development and promotion of the event via social networks of FB etc will create an impact on the bloggers and will facilitate the members to communicate, in order to support the brand/product and event (Ians, 2017). Event programmes, like Red Bull, sometimes do the same.

Community member does not stop to talk about RedBull, because, literally, the energy beverage company really never ceases to host celebrations involving people. The major market leader initiatives in the industry are: the squad which distributes samples for fun and buzzing, the constant' student- brand Manager Program' for spreading awareness through events near campus, RedBull initiated talent shows and reporter event (sponsored journalism) in the campus.

\subsection{Conversation on Supreme Customer Support:}

The companies throughout the world are much oriented towards the development through enhanced customer experience customer support. These companies have the right strategic plan, if by any means are able to generate discussion on customer experience of customer. A report states that the likelihood of a sale to an existing customer is 60- $70 \%$, whereas the likelihood for novel buyers is 5- 20\% (Hull,

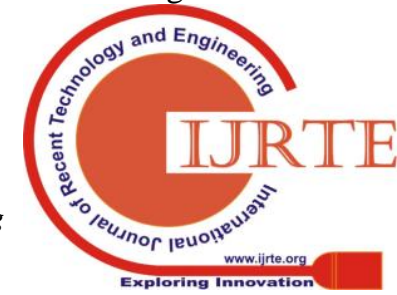


2013). Believing this figure is effective; companies should enhance the customer support and also initiate the discussion on the better customer support through virtual network. Building better services for customers, is strategy for transforming customers into supporters who won't stop the brand discussion Gifts and promotions are not important, but rather how people maintain interaction is important (Hull, 2013).

\subsection{Easy for Review by Community Members:}

Consumers face difficulty in leaving comments in reviews, and facilitate recommendation in e-WoM. Simplifying the process by which the customers communicate with brands, facilitating inspection of their goods or services is the only method to boost the volume of customer review (Aciar, 2007).

The oldest form of promotion, i.e. Word of the mouth is still crucial in today's high-tech world. The distinction is, companies should care the people if they don't send the message personally. Not sending the message is either intentional, if customer is not interested, or it is unintentional, may be arrived due to problems in sending. Problem of sending the message can be removed by simplifying the approval process. There are few support system, that needs to be addressed as mentioned below in order to make e-WoM effective.

\subsubsection{Enhancing Word of Mouth and Referrals:}

The reason for creating e-WoM is facilitated by a survey; it says that the customers try to prevent the discomfort they have, by decreasing the gap. Customer always tries to prevent stress and anxiety. The anxiety can be reduced if the gap of concern is filled. The strategy to attract consumers to boost Mouth's e- Word campaigns and their references is to address the gap that can be solved by reducing the worries and concerns. The same implication is recommended by Hennig-Thurau, et.al, (2004). Reducing the worries of a customer, if supported by companies support system, always shows the better experience o a customer and in turn it increases the referrals on virtual network through e-word of mouth.

\subsubsection{Lead through Education:}

This strategy has been adopted mostly by profitable companies of the globe and is extremely simple. Every day millions of web searches are performed to ask questions. The greatest marketing professionals know the value of education and only provide what the customer expects (Charlie, 2019). Answers of common questions can be facilitated in consultation with an expert to make website attractive and to enhance references of good work on other searching platforms. The company should work that way so that it can demonstrate the knowledge. The knowledge dissemination always helps in earning the respect in the society, as it helps in developing the link between respect and credibility gap (Charlie, 2019). In result customer initiates the good intention of company in the form of discussion, sometimes threaded discussion on virtual network through e-WoM.

\subsubsection{Active and Serious:}

The companies should undertake the campaigns seriously as it helps in building the credibility among the customers. In order to show the seriousness of efficient campaigns, and to have the continuous attachment of the customers, it is necessary for marketer to write and load the white paper personally or from other source every month, should also host a webinar and a live event (Kristen, 2019). In this regard it is necessary to mention, that a team of freelancers, to write columns or to produce the events are widely available. The company with content strategy will have a strategy of success in order to get the new followers, engagers/ influencers.

The most important thing to be successful is to understand that how the brands are connecting with humans, apart from implementing advanced technology. In other words, we can say that to give the focus to deeper insights it is necessary to understand and apply human for human. Therefore, it is necessary to know what society like and want to want to talk, along with identifying the people who can help in getting the message out there.

\subsection{Continuous Monitoring:}

E Word of Mouth has surrounded every aspect of consumer purchase. In recent years, Data Analytic has been used by the marketer to understand the need of customer and E Word of Mouth is helping them in their quest. Data Analytics has made all this possible and this has entered into every corner of our social life. Many e-commerce companies, media outlets and service companies are taking the help of Data Analytic in order to serve customers in a more efficient way. In recent years, some analysis firms have used Data Analytics to predict the success rate of the movie and this trend is slowly picking up.

Artificial Intelligence is another tool which may be used by marketers while analysing e-Word of Mouth. AI can be used to record various human expressions such as facial expression of customer while using a service such as while watching a movie. This expression may be stored as a data and then with the help of Data Analytics, it will help the marketer to understand the complex behavioural interpretation of their customer.

\section{CONCLUSION}

It has been revealed from various researches that for the better results in terms of influencing the behaviour of the consumers and to sale the products effectively, companies must participate actively in certain online consumers' communities and provide all the necessary and complete product information. This is important as more and more customers are on online platforms and are regularly exposed to a number of websites with regard to product or service. The most relevant and complete information will lead to higher information adoption of customers.

Present generation of internet mediators does not allow face- to- face contact with like the old pattern and thus lacks the depth of opinion and contract reference. Almost every e commerce sites at the present proposes internet platform featuring user reviews of the products they distribute and sale, perhaps to accommodate the intrinsic weakness of the personal contact. This chapter discussed the theoretical framework with regard to e-WoM. The theoretical frame includes conceptual description, e-WoM classification, significance and the approaches adopted useful in behavioural assessment. 


\section{E-Word of Mouth: Strengthening the Strategic Tool of Digital Marketing}

Through few success stories the chapter has briefed how the eWoM has generated the big customer base and made the companies successful in attracting the customers. It further explained the methods to be applied in order to increase the attraction of e-word of mouth as e-WoM source have a noteworthy function in customer decision making for purchase.

\section{REFERENCES}

1. Abubakar, A. M., \& Ilkan, M. (2016). Impact of online WOM on destination trust and intention to travel: A medical tourism perspective. Journal of Destination Marketing \& Management, 5(3), 192-201.

2. Aciar, S., Zhang, D., Simoff, S., \& Debenham, J. (2007). Informed recommender: Basing recommendations on consumer product reviews. IEEE Intelligent systems, 22(3).

3. ACNielson. (2007) Trust in Advertising: A Global Nielsen Consumer Report, October.

4. Ayeh, J. K. (2015). Travellers' acceptance of consumer-generated media: An integrated model of technology acceptance and source credibility theories. Computers in Human Behavior, 48, 173-180.

5. Bagozzi, R. P. (2007). The legacy of the technology acceptance model and a proposal for a paradigm shift. Journal of the association for information systems, 8(4), 3 .

6. Beer Jay (2019) Influencer Marketing Platforms, Retrieved on 09/02/2019 from

https://influencermarketinghub.com/influencer-marketing-what-why-ho w-to-guide/

7. Breazeale, M. (2009). Word of mouse-An assessment of electronic word-of-mouth research. International Journal of Market Research, 51(3), 1-19.

8. Brown, C., Burgess, F., \& Braithwaite, V. A. (2007). Heritable and experiential effects on boldness in a tropical poeciliid. Behavioral Ecology and Sociobiology, 62(2), 237-243.

9. Cacioppo, J. T., \& Petty, R. E. (1984). The elaboration likelihood model of persuasion. ACR North American Advances.

10. Cantallops, A. S., \& Salvi, F. (2014). New consumer behavior: A review of research on eWOM and hotels. International Journal of Hospitality Management, 36, 41-51.

11. Charlie C, (2019), Wix Review 2019: 7 Crucial Things to Know, retrieved on 13/02/2019 from https://www.websitebuilderexpert.com/website-builders/wix/wix-review/

12. Cheung, C. M., \& Thadani, D. R. (2012). The impact of electronic word-of-mouth communication: A literature analysis and integrative model. Decision support systems, 54(1), 461-470.

13. Chevalier, J. A., \& Mayzlin, D. (2006). The effect of word of mouth on sales: Online book reviews. Journal of marketing research, 43(3), 345-354.

14. Daugherty, T., \& Hoffman, E. (2014). eWOM and the importance of capturing consumer attention within social media. Journal of Marketing Communications, 20(1-2), 82-102.

15. Davis, F. D. (1989). Perceived usefulness, perceived ease of use, and user acceptance of information technology. MIS quarterly, 319-340.

16. Dellarocas C, (2003) The digitization of word of mouth: Promise and challenges of online feedback mechanisms. Management Science, Vol. 49, No. 10 , pp. $1407-1424$.

17. Dougherty Jim, (2015) 9 Word-of-Mouth Campaigns That Rocked retrieved on 13/02/2019 from https://www.cision.com/us/2015/03/9-word-of-mouth-campaigns-that-ro cked/

18. Duhan Punita, \& Singh Anurag, (2013a), Social Media : A Paradigm Shift in Integrated Marketing Communication, Integral Review , 6(2), pp 1-12

19. Duhan Punita, \& Singh Anurag, (2013b), Impact of Usefulness, Ease of Use, Enjoyment, Attitude and Subjective Norms on Behavioural Intensions and Adoption of Virtual Communities: An Empirical Study, Journal of IMS Group, 2 (1), pp 1-10

20. Fishbein, M., \& Ajzen, I. (1975). Belief, attitude, intention and behavior An introduction to theory and research.

21. Gómez-Suárez, A., Nelson, D. J., \& Nolan, S. P. (2017). Quantifying and understanding the steric properties of N-heterocyclic carbenes. Chemical Communications, 53(18), 2650-2660.

22. Hennig-Thurau, T., Gwinner, K.P., Walsh, G. and Gremler, D.D. (2004), Electronic word-of-mouth via consumer-opinion platforms: what motivates consumers to articulate themselves on the Internet? Journal of Interactive Marketing, Vol. 18 No. 1, pp. 38-52.
23. Henning-Thurau, T. (2004). Motive des lesens von kundenartikulationen im internet: theoretische und empirische analyse. In Konsumentenverhalten im Internet (pp. 171-193). Gabler Verlag.

24. Hull P, (2013), Don't Get Lazy About Your Client Relationships, retrived on 13/02/2019 from https://www.forbes.com/sites/patrickhull/2013/12/06/tools-for-entrepren eurs-to-retain-clients/\#7090b5502443

25. Ians, (2017), Nargis Fakhri clicks 'Pink Selfie' to support breast cancer awareness, retrieved on 13/02/2019 from https://www.indiatvnews.com/entertainment/bollywood/nargis-fakhri-pi nk-selfie-to-support-breast-cancer-awarness-17744.html

26. Jhagadia, (2014), Abbott to develop nutrition products suited to Indian tastes, retrieved on 13/02/2019 from https://www.thehindubusinessline.com/companies/Abbott-to-develop-nut rition-products-suited-to-Indian-tastes/article20888339.ece

27. Katz, E., Haas, H., \& Gurevitch, M. (1973). On the use of the mass media for important things. American Sociological Review, 38(2), 164-181

28. Kim, E. E. K., Mattila, A. S., \& Baloglu, S. (2011). Effects of gender and expertise on consumers' motivation to read online hotel reviews. Cornell Hospitality Quarterly, 52(4), 399-406.

29. Kristen M, (2019), How to Create and Host a Webinar: The Ultimate Start-to-Finish Guide (+ Expert Advice), retrieved on 13/02/2019 from https://learn.g2crowd.com/how-to-create-and-host-a-webinar

30. Litvin, S. W., Goldsmith, R. E., \& Pan, B. (2008). Electronic word-of-mouth in hospitality and tourism management. Tourism management, 29(3), 458-468.

31. Martin B and Simone H, (2012), Political Change in the Middle East: An Attempt to Analyze the "Arab Spring", retrieved on 13/02/2019 from https://www.giga-hamburg.de/system/files/publications/wp203_beck-hu eser.pdf

32. Mayfield A (2008). A commander Strategy for Social Media retrieved on 13/02/2019 from www.dtic.mil/dtc/tr/fulltext/u2/a535374.

33. McMillen Jacob, (2016), Word-of-Mouth Marketing: Building a Strategy That Really Works, retrieved on 13/02/2019 from https://www.yotpo.com/blog/word-of-mouth-marketing/

34. Mishra Yog, Singh Anurag (2018), "Exploring the Determinants of e-WoM influence: An Empirical Study on Tourist visiting Varanasi" Management Today, 8, (3), pp 266-273

35. Mishra Yog, Singh Anurag, (2017) Role of E word of Mouth in M Commerce Age: An Exploration, International Journal of Marketing \& Financial Management, 5 (3), pp 65-76

36. Reza Jalilvand, M., \& Samiei, N. (2012). The effect of electronic word of mouth on brand image and purchase intention: An empirical study in the automobile industry in Iran. Marketing Intelligence \& Planning, 30(4), 460-476.

37. Shu, M., \& Scott, N. (2014). Influence of social media on Chinese students' choice of an overseas study destination: An information adoption mode perspective. Journal of Travel \& Tourism Marketing, 31(2), 286-302.

38. Singh Anurag , (2014), CSR communication through Social Media: A Strategy for Brand Building and Market Growth, Review of Professional Management, Vol 12, No.1, pp 82-89

39. Singh R, (2014), PediaSure bets on young \& smart moms to take on the big boys, retrieved on 13/02/2019 from //economictimes.indiatimes.com/articleshow/38022192.cms?utm_sourc e=contentofinterest\&utm_medium=text\&utm_campaign=cppst

40. Sotiriadis, M. D., \& Van Zyl, C. (2013). Electronic word-of-mouth and online reviews in tourism services: the use of twitter by tourists. Electronic Commerce Research, 13(1), 103-124.

41. Sugita Katyal, (2018), Netflix looks at the bigger picture in India, retrieved on 13/02/2019 from https://www.fortuneindia.com/opinion/netflix-looks-at-the-bigger-pictur e-in-india/102120

42. Sussman, S. W., \& Siegal, W. S. (2003). Informational influence in organizations: An integrated approach to knowledge adoption. Information systems research, 14(1), 47-65.

43. Thorson, K. S., \& Rodgers, S. (2006). Relationships between blogs as eWOM and interactivity, perceived interactivity, and parasocial interaction. Journal of Interactive Advertising, 6(2), 5-44

44. Zephoria Digital Marketing, 2018, The Top 20 Valuable Facebook Statistics - Updated January 2019, retrieved on 13/02/2019 from https://zephoria.com/top-15-valuable-facebook-statistics/ 